\title{
Traditional knowledge on herbal drinks among indigenous communities in Azad Jammu and Kashmir, Pakistan
}

Neelam Rashid ${ }^{1,3}$, Rodrigue Castro Gbedomon ${ }^{2 *}$, Mushtaq Ahmad ${ }^{3}$, Valère Kolawolé Salako², Muhammad $\mathrm{Zafar}^{3}$ and Khafsa Malik ${ }^{3}$

\begin{abstract}
Background: Traditional knowledge about the use of medicinal plants for herbal drinks (HDs) is not well documented in the Azad Kashmir region despite their widespread use. This study highlights the taxonomic diversity and traditional knowledge on medicinal plants used for HDs while examining the diversity of diseases treated with HDs in the study area.

Methods: Individual discussions were conducted with 255 informants (84 women and 171 men). Data gathered included (i) informant age and gender, (ii) HD species and respective plant parts used, (iii) health disorders treated, and (iv) mode of preparation and utilizations. Quantitative ethnobotanical indices including relative frequency of citation (RFC), informant consensus factor (ICF), and use value (UV) were used for data analyses.

Results: Altogether, 73 medicinal plants belonging to 40 families and 66 genera were reported to be used in HD preparations, with Asteraceae being the richest family. The average number of HD species cited was $9.09 \pm 0.17$ per informant and did not vary either by age or gender. In addition, men and women, and adults and the young used the same pool of species (dissimilarity nearly zero). The most used plant parts were leaves (20.00\%), roots (17.25\%), and fruits (16.47\%). Based on UV, the top five most used species were Valeriana jatamansi, Isodon rugosus, Onopordum acanthium, Acacia nilotica, and Viola canescens; and the UV was similar among gender and age categories too. The most utilized herbal preparation forms included decoctions, infusions, and tea. One hundred and eleven diseases grouped into 13 ailment categories were reported to be cured using HDs. The main category of disease treated with HDs was gastrointestinal (GIT) disorders (RFC $=17.43 \%$ ). Relatively few species were used by a large proportion of informants for each category of ailment (ICF $\geq 0.60$ ). Only one species was used for "glandular disorders" and "eye diseases" (ICF =1).

A novelty of about 22\% (16 species) was recorded for HD species in the present work.
\end{abstract}

Conclusion: The diversity of medicinal plant species used as HDs and the associated traditional knowledge are of considerable value to the indigenous communities of the Azad Kashmir region. Therefore, there is a need for conservation and preservation of medicinal HD species as well as the wealth of indigenous knowledge. The conservation effort should be high for species in the ailments categories glandular disorders and eye diseases. The therapeutic uses of HDs have provided basic data for further research focused on phytochemical and pharmacological studies and conservation of the most important species.

\footnotetext{
* Correspondence: gbedomon@gmail.com

${ }^{2}$ Laboratoire de Biomathématiques et d'Estimations Forestières, Faculty of

Agronomic Sciences, University of Abomey-Calavi, 04BP 1525 Cotonou, Benin

Full list of author information is available at the end of the article
} 


\section{Background}

Traditional medicine (TM), also known as complementary and alternative medicine in developed countries, is widely used and is of rapidly growing interest in health care systems all over the world. About $80 \%$ of the world's population, particularly in developing regions, relies on TM practices to meet their health care needs $[1,2]$. TM is very popular and attracts much attention from a large spectrum of health system stakeholders, not only for its accessibility and affordability for poor people but also because of the risk of adverse effects of chemical drugs in allopathic medicine. As a recognition of its importance and as a response to skepticism and disbelief from some stakeholders, in 2002, the World Health Organization defined a strategy to address issues of policy, safety, efficacy, quality, access, and rational use of TM [3]. TM includes medication therapies and nonmedication therapies. Whereas the latter are carried out primarily without the use of medication, the first involve the use of herbal medicines [4-6], animal parts [7-10], and minerals $[11,12]$.

Among the medication therapies, herbal medicine or phytotherapy is encountered worldwide, and its use is very ancient. Human use of plants as medicines was dated to at least the Middle Paleolithic age some 60,000 years ago $[13,14]$. The Himalayan region comprised of Afghanistan, Bangladesh, Bhutan, China, Myanmar, Nepal, Pakistan, and India is reputed to be a rich storehouse and hotspot of valuable medicine plant species. About 1748 plant species corresponding to $21.85 \%$ of the local 8000 angiosperm species are used for medicinal purposes [15].

In Pakistan, the flora is quite rich and is estimated to consist of about 6000 species of higher plants of which 600 to 700 species, the majority growing in the wild, are used for medicinal purposes [16]. Throughout the country, TM using plant species is popularly practiced among a large segment of its population [17-20]. Eighty percent of people belonging to the rural areas still depend upon the herbal medicines in Pakistan. The most realistic and commonly employed therapy for diseases is to make infusions or decoctions from different plant parts [21]. Local market systems named "Pansara" specifically dealing with medicinal business have been reported [16, 22-24], with important quantities of plants exchanged locally or exported. For some years, important concerns due to excessive use of herbal medicine have arisen and are related to the conservation issue of medicinal plant species [16] and adulteration of botanical medicine [24]. Indeed, the majority of medicinal plants used for the herbal drug industry and local communities come from wild collection. Overexploitation and unsuitable collection methods are contributing to the extinction of some medicinal plants and bringing others to the brink of extinction [16]. Beyond the conservation issue, the excessive use of medicinal plants may lead to the misidentification of adulterant plants, hence compromising the quality control and standardization [25]. Moreover, ethnobotanical medicine in Pakistan is still a huge field of investigation. The last review on medicinal plants in Pakistan [25] evidenced the gaps of knowledge on herbal medicine and called upon extensive research. This paper aims at contributing to this ongoing body of knowledge in herbal medicinal, focusing on HDs.

HDs refer to beverages made from the infusion or decoction of herbals, spices, fruits, or other plant materials, served cold or hot. They include herbal teas, fruit drinks, infusions, and decoctions. HDs are highly appreciated mostly because of their therapeutic purposes [26]. In Pakistan, the available literature on medicinal plants used for HDs is recent and preliminary [2, 27], and important issues remain unanswered and insufficiently documented. Using the region of Azad Jammu and Kashmir in Pakistan, this study aims at:

1. Assessing the taxonomic diversity of plants used for HDs. The medicinal plant richness of Pakistan is estimated to be about 600 to 700 plant species [25]. What is the taxonomic composition of the pool selected for HD preparation? Based on the nonrandom selection theory $[28,29]$, which predicts that medicinal plant selection is not random, it is expected that the number of medicinal plant species used for HDs differs across botanical families.

2. Assessing the traditional knowledge on HDs and its relationship with age and gender. Indeed, the use of medicinal plants is based on trial and error and is passed on from one generation to another, after refinement and additions [30]. What is the traditional knowledge (species uses, plant parts used, mode of preparation, etc.) related to HD preparation? Because various individual sociocultural and demographic traits, mainly gender and age, are correlated with an individual's level of plant knowledge [31-33], we expected traditional knowledge related to HDs to be associated with age and gender. With women and older people tending to have a greater knowledge of local medicinal flora $[31,34]$, we hypothesized that traditional knowledge on HDs is mostly held by women and old people in Pakistan.

3. Assessing the diversity of diseases treated by HDs. About $10-12 \%$ of plants in Pakistan are used to meet health care needs. In the special case of HDs made of medicinal plants, what diseases are treated, and which plants are solicited? We expected some diseases to be treated by a restricted set of plants. 


\section{Methods}

\section{Study area}

The region of Azad Kashmir is positioned between $34^{\circ} 22^{\prime}$ North latitude and $73^{\circ} 28^{\prime} 00$ East longitude. The total area is about $13,297 \mathrm{~km}^{2}$ [35]. The study sites included eight districts; Muzaffarabad, Mirpur, Kotli, Bagh, Poonch, Palandari, Neelum, and Bhimber. The region of Azad Jammu and Kashmir is characterized by a craggy landscape, mountains, waterfalls, paddocks, river, streams, plains, and forests [36] (Fig. 1).

The region of Azad Jammu and Kashmir has varied climatic characteristics with temperate, humid, subtropical, and sub-alpine eco-regions. Due to peculiar geographical and climatic conditions, this area is gifted with a rich floral diversity [37]. The local inhabitants of Azad Jammu and Kashmir belong to various cultures and speak different local or native languages such as Pahari, Pothohari, Hindko, and Gojri, and the Urdu language is also well-known to the local people.
Ethnographic and socio-economic characteristics of the Azad Jammu and Kashmir region

Overall in the Azad Jammu and Kashmir region, Mughals, Syed, Raja, Chaudhary, and Maliks are the prominent castes. Azad Kashmir is generally considered as a Pahari speaking region. There is a large Gojri community and some pockets of Kashmiri, especially in Neelam Valley regions. Hindu and Punjabi are also spoken in Muzaffarabad and Bhimber areas, respectively, adding to the cultural diversity of this region. Urdu enjoys the status of official language in the region. Kashur, the language of Kashmir, is spoken by families residing in different parts of Azad Kashmir [38]. The population of the valley is approximately over 4 million. The population density in Azad Kashmir is estimated at 343.5 inhabitant $/ \mathrm{km}^{2}$.

Internally, the region of Azad Jammu and Kashmir is organized into three administrative divisions including Mirpur, Poonch, and Muzaffarabad. The divisions are further divided into 10 districts and 30 sub-districts or

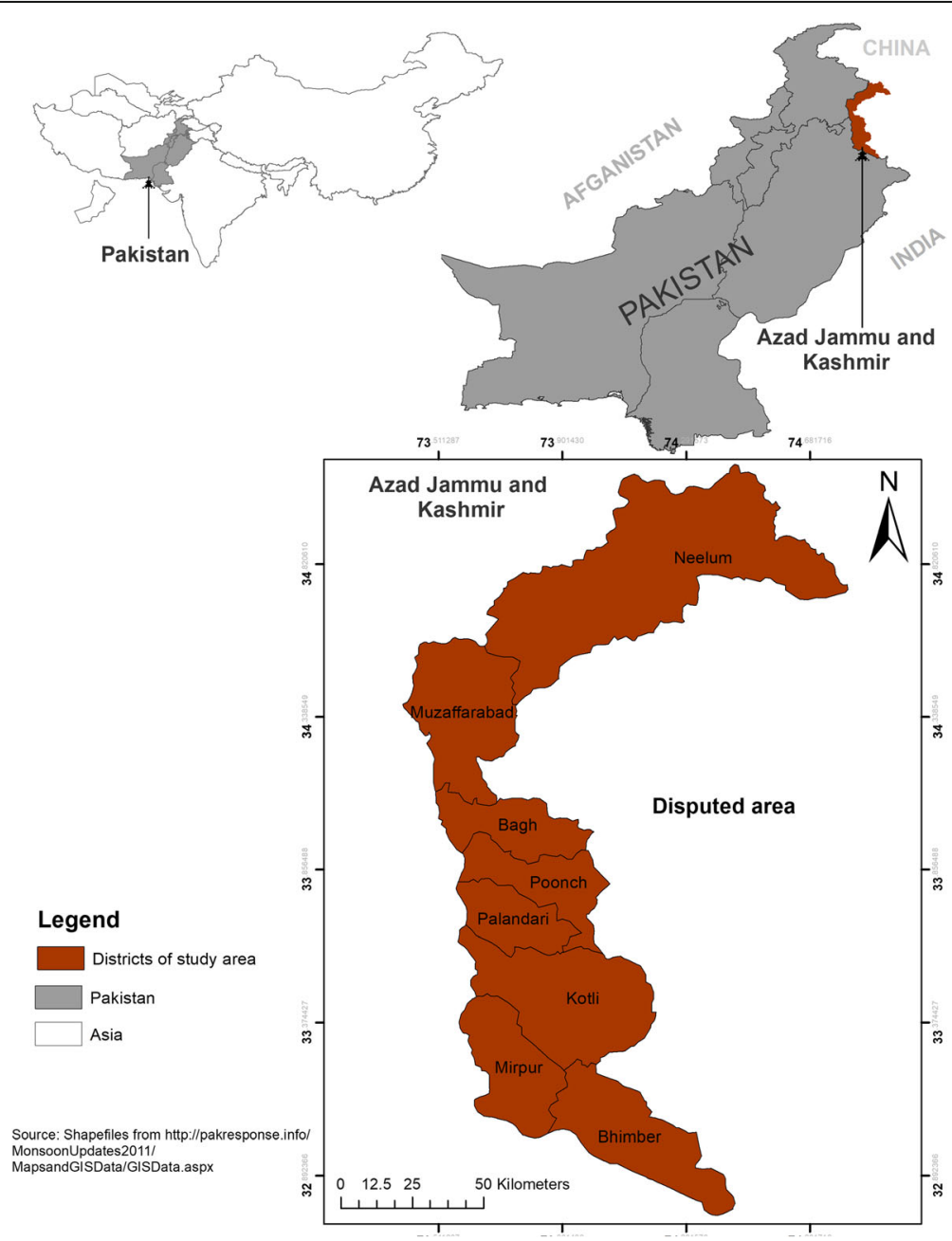

Fig. 1 Map of Azad Jammu and Kashmir 
Tehsils. Most of the Kashmiris live in villages and are dependent on agriculture. Local people are primarily affiliated with agriculture and also rear livestock. The plain areas of this region have an agricultural economy primarily dependent on rainfall. Maize, wheat, and rice are the main crops, and beans and peas are also cultivated in the area. Tourism has greatly improved the socioeconomic conditions of the area by providing job opportunities to local people. Local people work in hotels and restaurants, as guides and jeep drivers, and some have opened shops at tourist resorts.

\section{Sampling and data collection Sampling}

The sampling method combined both probabilistic and non-probabilistic approaches. First, 5 villages were purposely chosen in each one of the 8 districts of the study area, for a total of 40 villages. The main criterion of selection was the prevalence of herbal medicine practice. Second, for each district, a sub-sample size of about 30 to 35 informants was chosen, for a total of 255 informants for the whole study area. A sample size of a minimum of 30 informants per district is the minimum size for a good approximation of the normal distribution [39] and for sound statistical analyses. Before entering each of the study areas, permission was sought from a local area leader after explaining the objectives of the study. From this leader, we took the name of the first key informant, whereas the rest of the respondents were selected by a snowball sampling technique [40]. Out of the 255 interviewed persons, $76 \%$ were male, and the remaining $24 \%$ were female. Thirty percent of informants were under 40 years old.

\section{Data collection}

The collection of data was undertaken by an experienced researcher who had a strong knowledge of the local languages and culture of Azad Jammu and Kashmir. Ethnobotanical data were collected during individual interviews and group discussions with informants. Questions asked during the interviews were related to sociodemographic characteristics of informants (name, age, gender, occupation, area, etc.) and plant information (local name of species, habitat, part used, disease treated, mode of preparation and utilization, dose of application, duration of treatment, status of the species, etc.). Interviews were conducted in the local language and lasted on average 15 to $30 \mathrm{~min}$ depending on interview conditions.

The specimens of the plants used in HDs were collected and preserved using herbarium techniques as suggested by [41]. Vouchers were first identified using the Flora of Pakistan and were sent to the National
Herbarium of Pakistan (http://herbarium.qau.edu.pk/) in Islamabad for formal identification and authentication.

\section{Concept clarification}

Herbal medicine, also known as herbalism or botanical medicine, is a medical system based on the use of plants or plant extracts to treat illness and to assist bodily functions. Sometimes, herbal remedies are prepared as drinks by following different techniques and are served hot or cold. They include herbal teas, fruit drinks, infusions, and decoctions prepared for medicinal purposes. This definition excludes "recreational tea" [26] and other beverages prepared as an infusion or decoction that are consumed primarily in a food fortification context or for their general socio-cultural and recreational value. There are different modes of preparation/utilizations of HDs (Table 1).

\section{Ethical consideration}

The data were collected with critical care by keeping in view the cultural values of local communities. Respondents were informed that the study was carried out for academic reasons and not for commercial purposes. Finally, informants acknowledged the concept and reached an agreement. Prior, informed consent was obtained for conducting interviews, and the researchers involved in the conceptualization of this study adhered to the ethical guidelines of the International Society of Ethnobiology [42].

\section{Statistical analyses}

Quantitative ethnobotanical indices including relative frequency of citation (RFC), informant consensus factor (ICF), and use value (UV) were used for data analyses.

\section{Taxonomic diversity of plants used in HDs by communities in Azad Jammu and Kashmir}

The taxonomic plant diversity was assessed through the calculation of the species richness, genera richness, and

Table 1 Definition of some concepts related to herbal drinks

\begin{tabular}{|c|c|}
\hline Herbal drinks & Definition \\
\hline Herbal tea $(H T)$ & $\begin{array}{l}\text { An herbal beverage made with flowers, leaves, and } \\
\text { soft stems of plants. Herbal tea is light combining } \\
\text { both recreational and medicinal purposes. }\end{array}$ \\
\hline $\begin{array}{l}\text { Herbal } \\
\text { infusion (HI) }\end{array}$ & $\begin{array}{l}\text { An herbal tea made from longer steeping or boiling } \\
\text { with a larger amount of herb. Herbal infusion is } \\
\text { exclusively used for medicinal purpose and to } \\
\text { provide body with high dose of vitamins and } \\
\text { minerals. Infusion is intended to extract vitamins } \\
\text { and volatile ingredients from the leaves and flowers. }\end{array}$ \\
\hline $\begin{array}{l}\text { Herbal } \\
\text { decoction } \\
(\mathrm{HD})\end{array}$ & $\begin{array}{l}\text { An herbal beverage made with roots, barks, seeds, } \\
\text { rhizomes, and woods and intended to extract mineral } \\
\text { salts and bitter principles from plants. Unlike } \\
\text { infusions, decoctions are left on the heat and } \\
\text { simmered for a length of time. }\end{array}$ \\
\hline $\begin{array}{l}\text { Herbal fruit } \\
\text { juice (HFJ) }\end{array}$ & An herbal beverage made with fruits. \\
\hline
\end{tabular}


family richness. The RFC of species, expressed as the ratio (in \%) between the numbers of informants who cited the species divided by the total number of surveyed informants, was used to identify the most frequently cited species.

\section{Local traditional knowledge on HDs in Azad Jammu and Kashmir}

Gender and age differences in the knowledge of HD species The species used for HDs were compared between men and women and between informants aged less than 40 years and informants aged 40 years and older using both quantitative and qualitative aspects. The rationale for this analysis was that number of species used may be similar, whereas the species used could be quite different. A Poisson generalized linear model (GLM) was used to assess the relationship between the number of species cited on one hand, and gender and age category and their interaction on the other. Analysis of similarities (ANOSIM) [43] was used to test whether there was a significant difference between men and women or informants aged less than 40 years and those aged 40 years and older with respect to species used. ANOSIM provides a way to test whether there is a significant difference between two or more groups of sampling units. ANOSIM operates directly on a dissimilarity matrix and is philosophically allied with non-metric multidimensional scaling ordination [44] in that it uses only the rank order of dissimilarity values. If two groups of sampling units are really different in their species composition, then compositional dissimilarities between the groups ought to be greater than those within the groups. The ANOSIM statistic $R$ is based on the difference of mean ranks between groups. It ranges from 0 to 1,0 indicating a completely random grouping and 1 indicating a completely different species composition.

Plant parts used for HDs First, a list of plant parts used for HDs was established. Next, the RFC of each plant part expressed as the proportion of informants who mentioned that plant part was computed as a measure of informant consensus on its use in an HD.

Preparation and mode of utilization The diversity of the preparation mode of HDs and its occurrence among informants was calculated using RFC. The utilization mode reported by informants was then described.

\section{Medicinal uses of HDs in Azad Jammu and Kashmir}

Informant consensus on medicinal uses of HDs To determine informant consensus on the spectrum of species used for each category of ailment, the ICF was calculated. Here, ICF estimates the relationship between the "number of use-reports in each category $\left(n_{\mathrm{ur}}\right)$ minus the number of species used $\left(n_{\mathrm{t}}\right)$ " and the "number of usereports in each category minus 1," as described in Eq. 1.

$$
\mathrm{ICF}=\frac{n_{\mathrm{ur}}-n_{\mathrm{t}}}{n_{\mathrm{ur}}-1}
$$

Values of ICF range from 0 to 1 . A high value (close to 1 ) indicates that relatively few taxa (usually species) are used by a large proportion of people, whereas a low value indicates that the informants disagree on the taxa to be used in the treatment within a category of illness.

UV of HD plant species and relationship with gender and age category of informants The importance of each single species in HDs was estimated using the relative UV [45], which is a modified version of the UV method introduced by Phillips and Gentry [46]. This modified version of UV (Eq. 2) captures all the known uses by an individual:

$$
\mathrm{UV}=\sum_{i=1}^{n} \frac{\mathrm{UR}_{\mathrm{i}}}{n}
$$

$\mathrm{UR}_{\mathrm{i}}$ is the number of use-reports mentioned by informant $\mathrm{i} . \mathrm{n}$ is the number of informants.

UV was used to identify the top 14 species in HDs, i.e., species with the highest values of UV. The data showed that for all top 14 species, each informant mentioned either one or no use of each single species (i.e., no informant mentioned more than one use for each single species). Therefore, a binomial logistic model was used to assess whether the UV of each of the top 14 species was related to gender and age category. The full model was first specified, and then a stepwise selection method based on AIC (Akaike information criterion) was used to select the parsimonious model.

All statistical analyses were implemented in R software [47], and the significance level was considered at alpha $=0.05$.

\section{Results}

Taxonomic diversity and life form of plants used in HDs in Azad Jammu and Kashmir

Seventy-three species belonging to 40 families and 39 genera were cited as being used for HDs. The richest family was Asteraceae ( 9 species) followed by Lamiaceae (7 species) and Fabaceae (5 species). Twenty-eight families had only one species, whereas seven families had only two species (Fig. 2). The most common genera reported were Solanum, Morus, and Mentha.

The 73 reported plant species were dominantly herbs $(69.86 \%)$. The remaining were comprised of shrubs (16.43\%), trees (12.35\%), and climbers (1.36\%). 


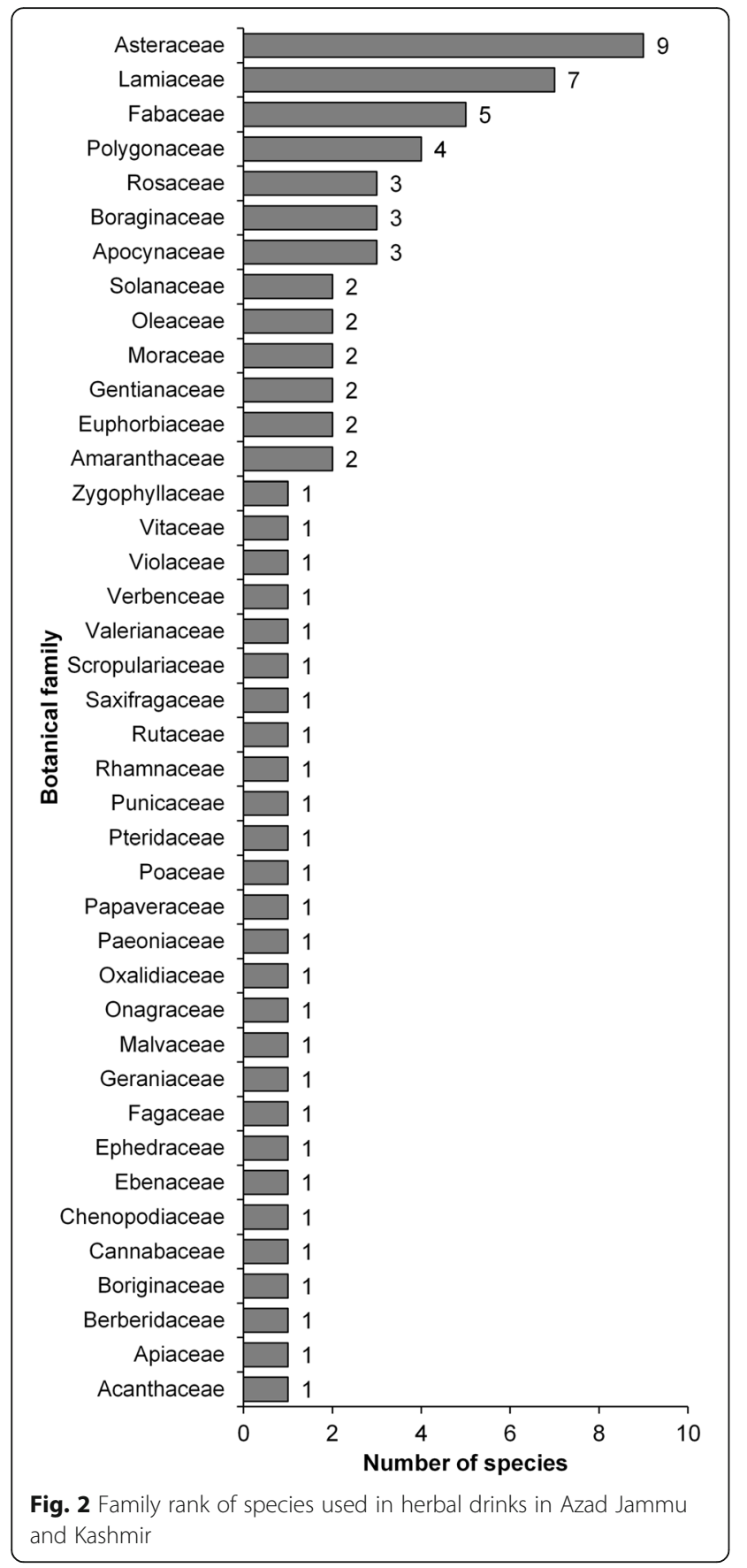

\section{Local traditional knowledge on HDs in Azad Jammu and \\ Kashmir}

Gender and age differences in the knowledge of HD species Quantitatively, the number of cited species per informant varied from 1 to a maximum of 17 . The number of reported species did not differ either between gender $(\mathrm{df}=1$, deviance $=0.78$, prob. $=0.376$ ) or between age categories $(\mathrm{df}=1$, deviance $=0.042$, prob. $=0.837)$. Although not significant, men cited on average more species $(9.23 \pm 0.21)$ than women $(8.82 \pm 0.32)$ (Fig. 3a). The average number
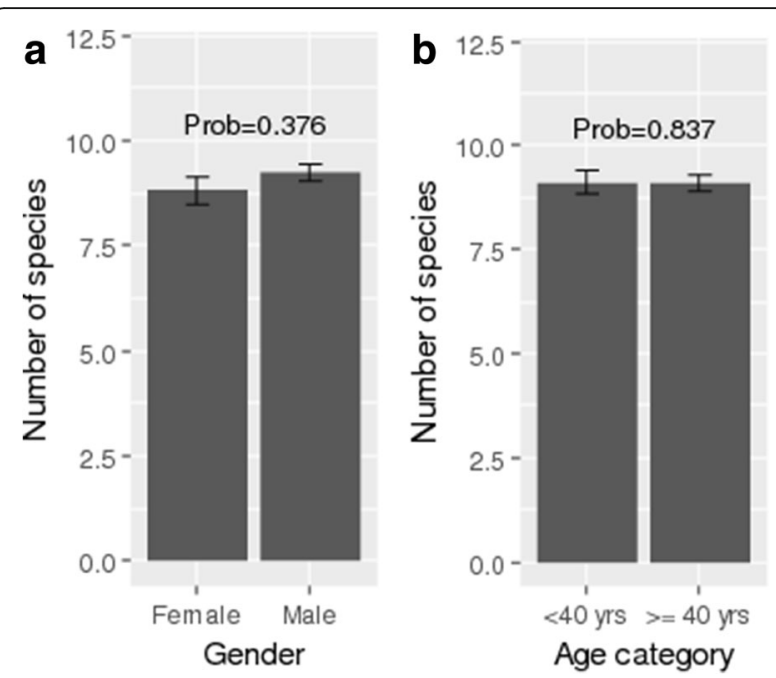

Fig. 3 a Diversity of plant species used in herbal drinks across gender. $\mathbf{b}$ Diversity of plant species used in herbal drinks across age categories

of cited species was $9.08 \pm 0.21$ for informants aged less than 40 years and $9.12 \pm 0.29$ for informants aged 40 years and older (Fig. 3b).

From a qualitative perspective, the ANOSIM R statistic was -0.0045 (prob. $=0.613$ ) and 0.0083 (prob. $=$ $0.225)$, respectively, for age and gender, indicating that both men and women or adults and the young used the same pool of species for HDs as illustrated by the quasi overlapping of the confidence ellipses (see Fig. 4).

\section{Plant parts used in HD preparation}

Overall, several parts of the plant were used in HDs, including leaves, roots, stems, fruit, seeds, rhizomes, and bark. Leaves was the most cited plant part (20.00\%) followed by roots (17.25\%) and fruits (16.47\%). Seeds and rhizomes were the least cited plant parts and grouped in the category "others."

\section{Preparation and modes of utilization of HDs}

Generally, HDs are prepared using simple methods depending on the plant material. The utilization modes included tea, juice, infusion, decoction, and beverage. The main form of utilization reported by informants was decoction. Decoctions are easier to make because plant parts are only to be boiled with water. Mostly, fresh plant parts are preferably used in preparation of HDs as reported by informants, and dried parts are also used. Informants reported that drying the plant parts may reduce the effectiveness of bio agents, because the ingredients present are damaged to some extent. Almost all preparations reported in the study (Table 2) were made from a single plant species with addition of sugar, water, and in some cases honey to increase the taste. 

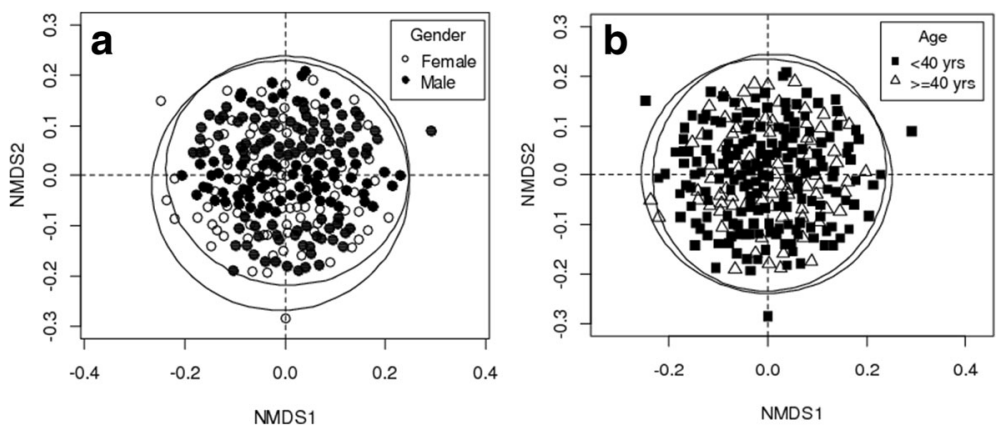

Fig. 4 a Similarity of plant species used in herbal drinks across gender. b Similarity of plant species used in herbal drinks across age categories

\section{UV of HD plant species}

The UV of species varied from 0.0039 to 0.2196 . The first 14 species with the highest values of UV are summarized in Table 3, with V. jatamansi, I. rugosus, O. acanthium, $A$. nilotica, and $V$. canescens being the top 5 most used species. The results of the models run to test how their UV varied across gender and age categories are summarized in Table 3 too. For all the species (except $V$. jatamansi), UV differed insignificantly ( $p$ value $>0.05$ ) between men and women and between age categories. UV of $V$. jatamansi was lower for men (est $=-0.88$, se $=0.38$, prob. $=0.021$ ).

\section{Medicinal uses of HDs in Azad Jammu and Kashmir}

One hundred and eleven (111) diseases grouped into 13 ailment categories were reported to be cured using HDs (Table 4). The most frequently cited diseases were gastrointestinal (GIT) diseases, respiratory diseases, and fevers. The least cited diseases were urinary disorders, oral diseases, and infectious diseases (Table 4).

For all 10 ailment categories, values of IFC were all greater than 0.60 (Fig. 5) indicating that relatively few species were used by a large proportion of informants for each category of ailment. In paricular, only one species, Quercus oblonga, was used for "glandular disorders," and only one other, Tagetes minuta, was used for "eye diseases" (Fig. 5).

\section{Discussion}

This study conducted within the indigenous communities of the region of Azad Jammu and Kashmir, Pakistan (i) assessed the diversity and life forms of plants used in HDs and tested for generation and gender differences in terms of known HD plant species; (ii) identified the most commonly used plants for HDs and the species-specific uses relationship with gender and generation; (iii) documented plant parts used in HD preparations, preparation mode, and mode of utilization; and (iv) determined the diseases treated by HDs and the diversity of plants used for each disease.

\section{HD plant diversity and life forms}

Most of the people inherited traditional knowledge from their elders and continued to transmit it from one generation to another [48]. Female informants were less numerous in the present study, owing to the reason that they were reluctant to give information, and used plants in homes and at a domestic level only. Among the reported plant families, Asteraceae was the most used in the treatment of various diseases. The reason for dominance of this family in plants used for HDs may be that the plants belonging to this family are naturally diverse and widespread in the study area $[49,50]$. Asteraceae is also the largest plant family in the world including over 1600 genera and 23,000 individual species, many of which are important for medicinal uses. This pattern is consistent with the non-random plant selection theory, which predicts that the number of medicinal species used in a botanical family in a given region would be linearly related to the total number of plant species in that family [51, 52]. Therefore, these plants are easily available and are consumed locally for various purposes, particularly medicinal uses. Family Asteraceae was also reported elsewhere to be the largest plant family in terms of the number of medicinal plants used in the treatment of various ailments [53, 54]. Such a similarity may be due to the presence of biologically active chemical constituents that make them medicinally important [55].

Herbs were exploited preferably than shrubs and trees because of their availability in addition to their high effectiveness for treatment of diseases than other growth forms. The frequent utilization of herbaceous medicinal plants was also described in studies conducted in various regions of the world [27, 56-59]. The reason for extensive utilization of herbs may be due to their easy accessibility as well as their therapeutic properties [60-62], as supported by the availability hypothesis, which predicts that plants are used for medicine because they are more accessible or locally abundant $[63,64]$. 


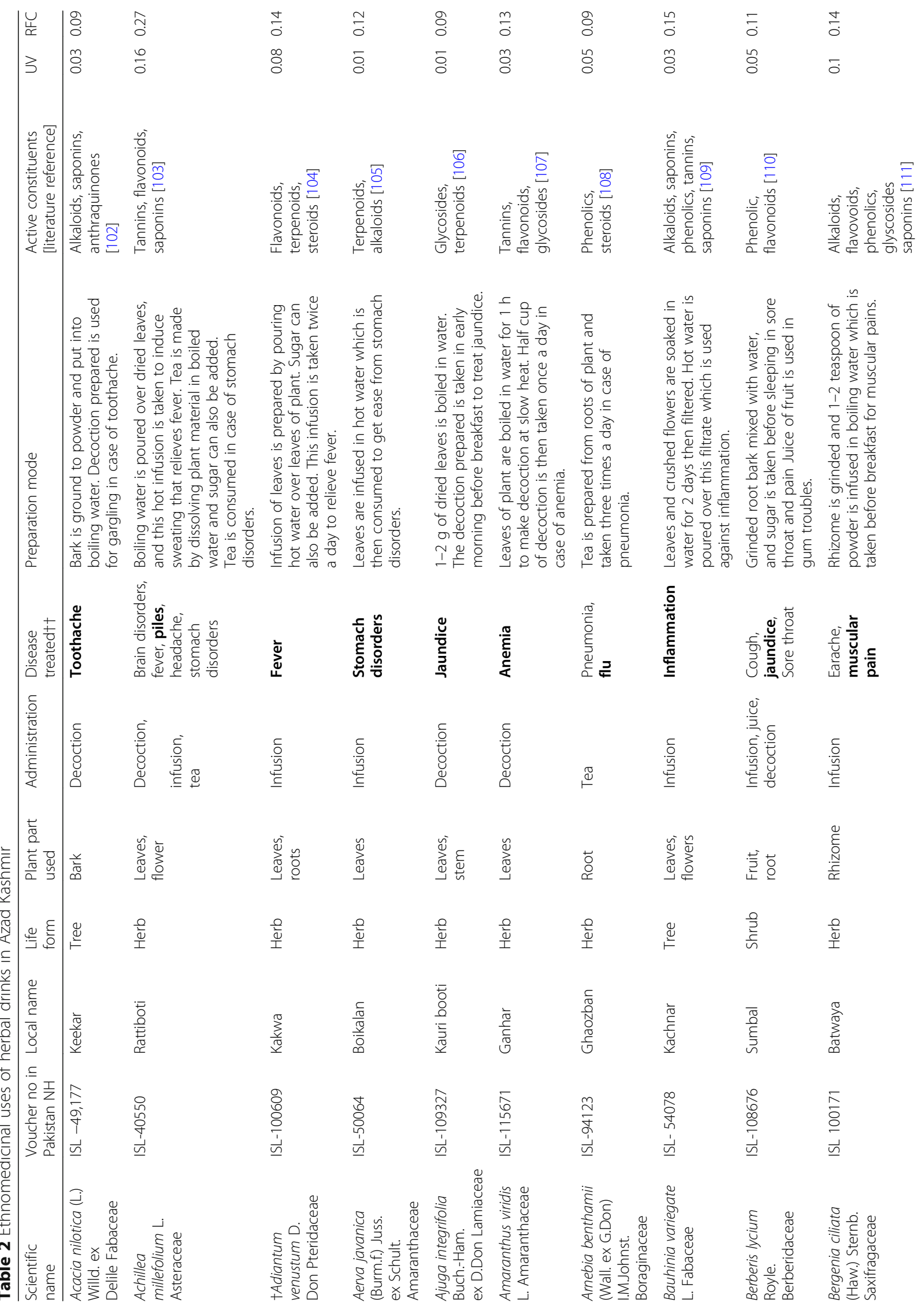




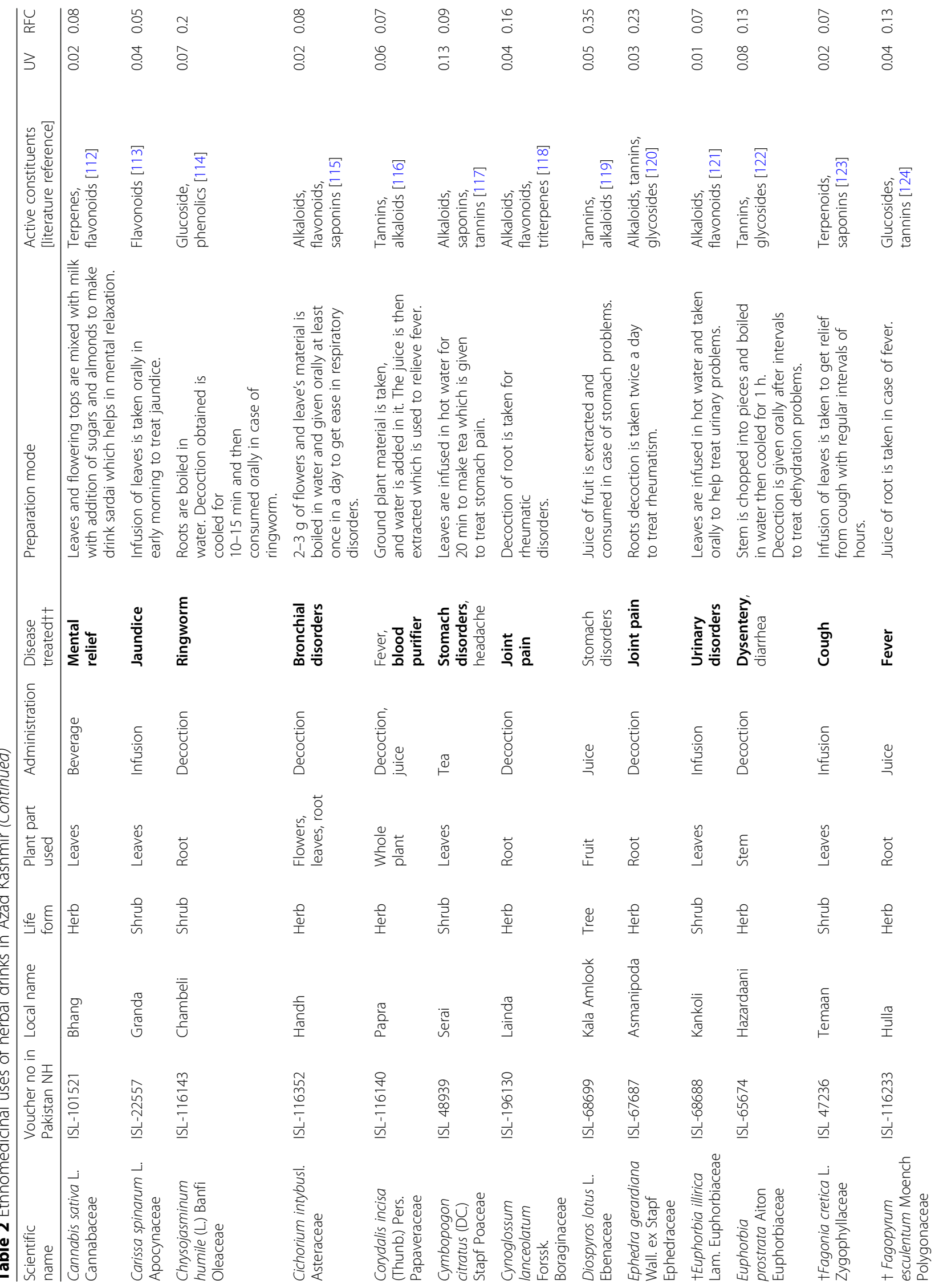




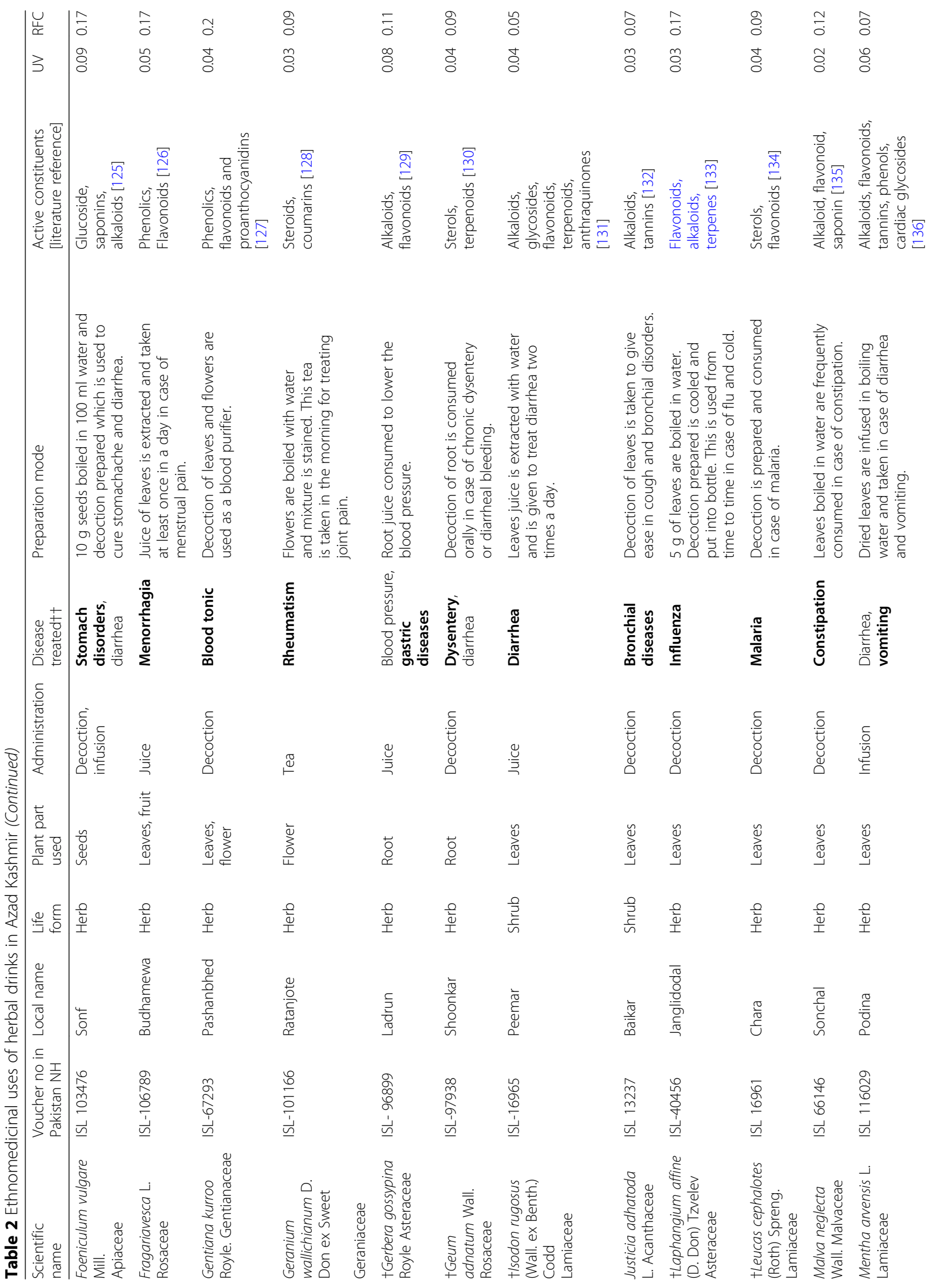




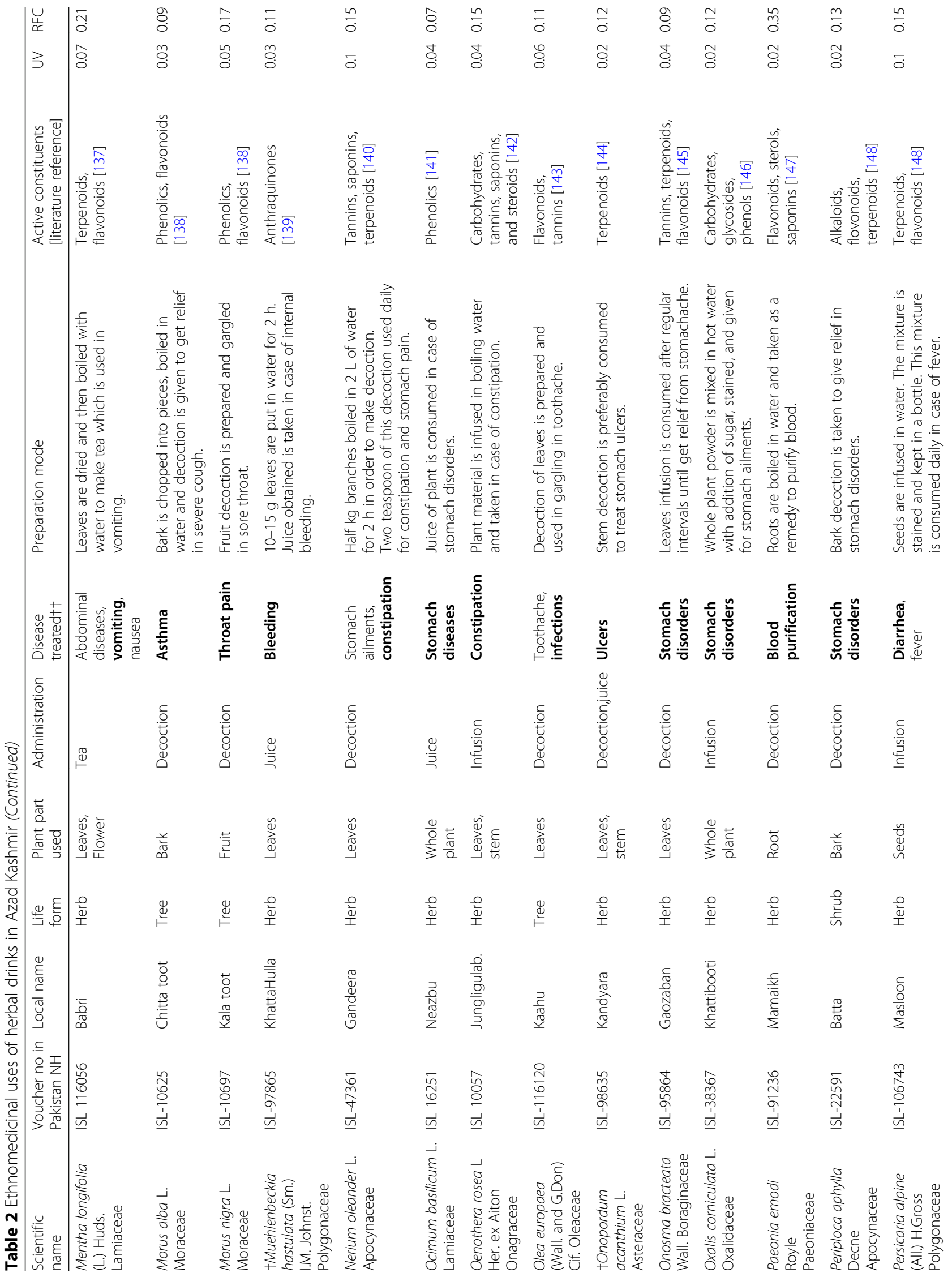




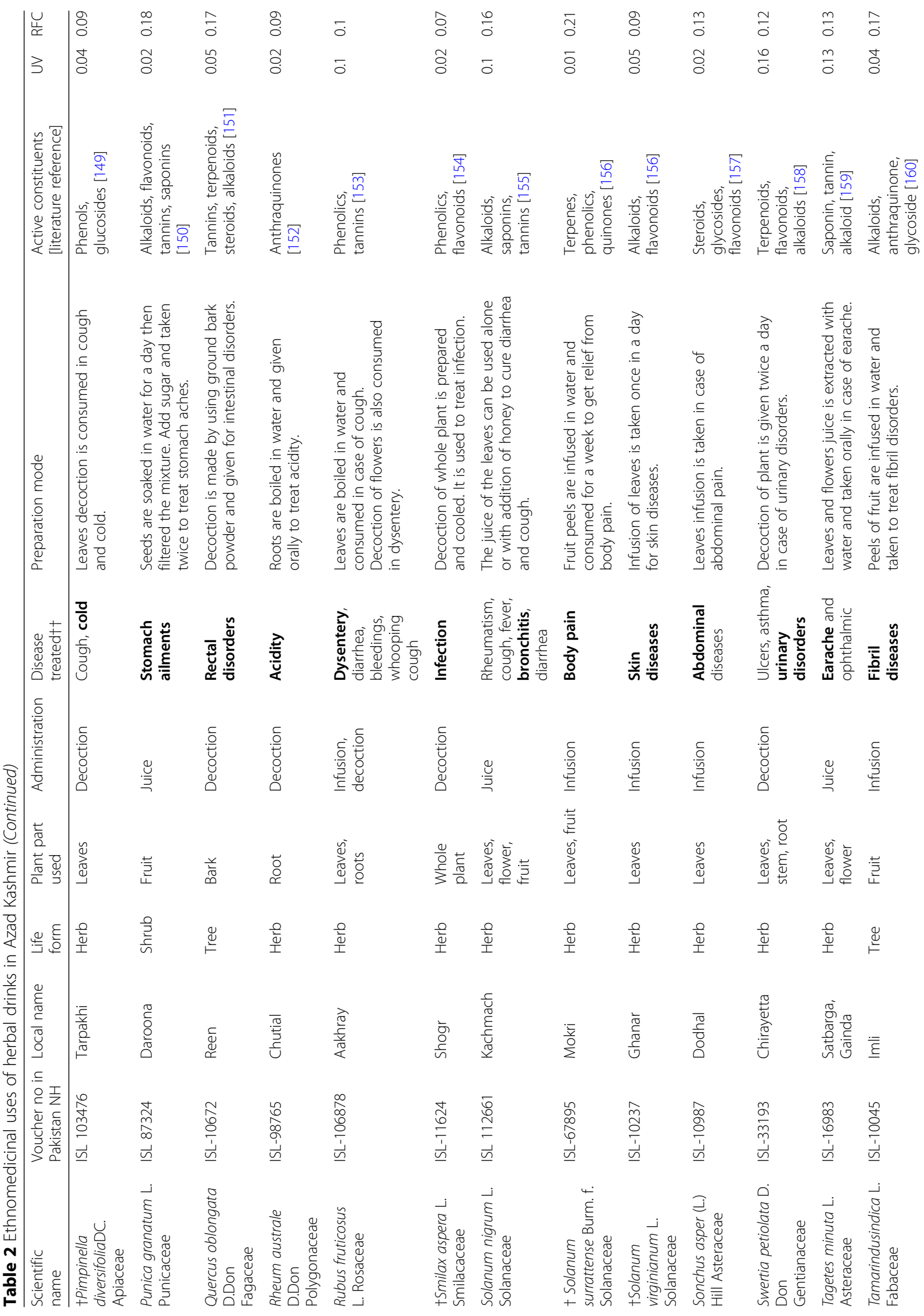




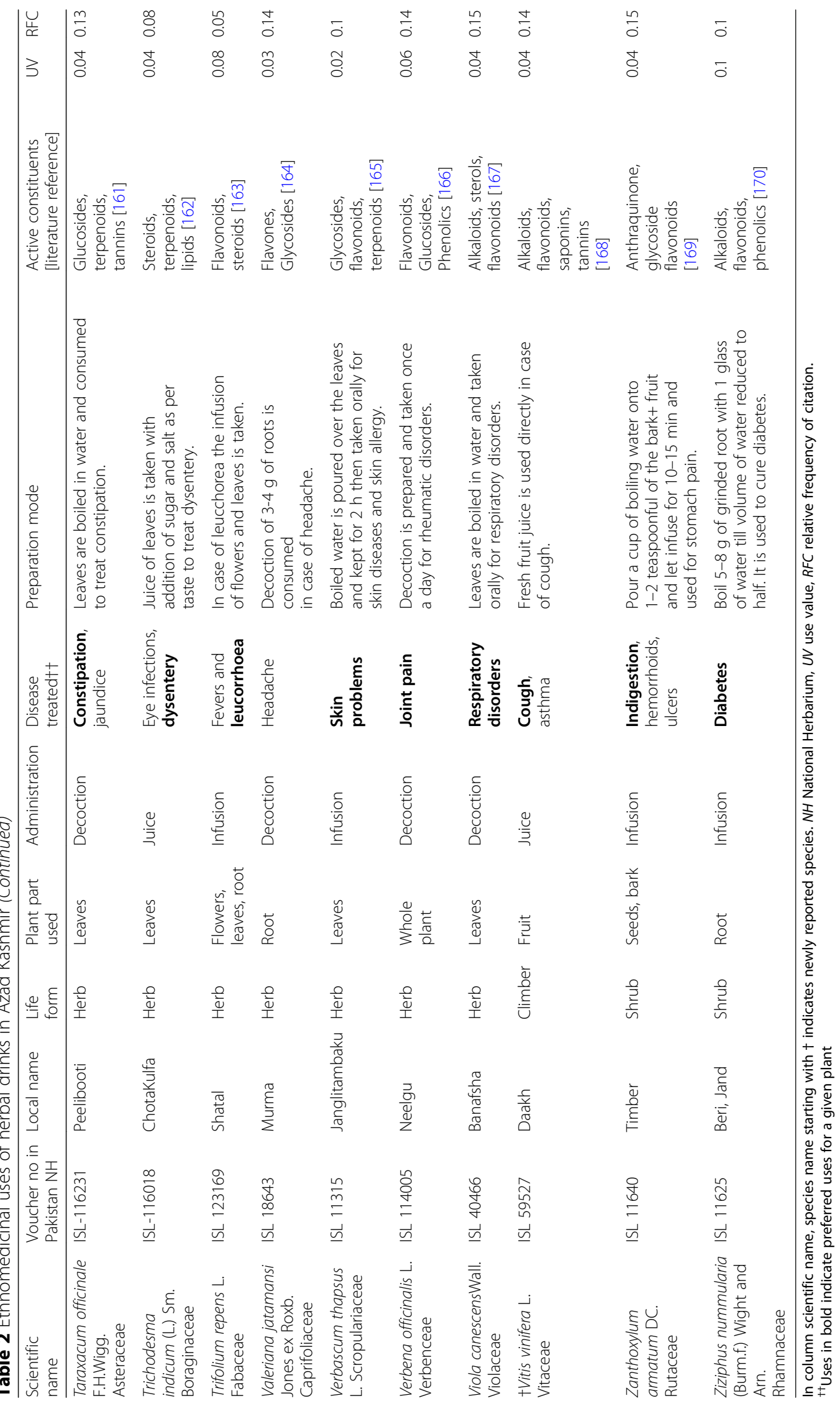


Table 3 Relationship between uses of the 14 species with the highest UV and gender and age of informants: summary of the Poisson GLM (SE = standard error, - absent from the parsimonious model)

\begin{tabular}{|c|c|c|c|c|}
\hline \multirow[t]{2}{*}{ Species } & \multirow[t]{2}{*}{ UV } & \multicolumn{3}{|c|}{ Gender $^{\dagger}$ : male } \\
\hline & & Estimate & SE & $p$ value \\
\hline Valeriana jatamansi Jones ex Roxb. & 0.2196 & -0.881 & 0.381 & 0.021 \\
\hline Isodon rugosus (Wall. ex Benth.) Codd & 0.0980 & - & - & - \\
\hline Onopordum acanthium L. & 0.0392 & - & - & - \\
\hline Acacia nilotica (L.) Willd. ex Delile & 0.0275 & - & - & - \\
\hline Viola canescens Wall. & 0.0275 & - & - & - \\
\hline Rubus fruticosus auct. (L.) & 0.0235 & - & - & - \\
\hline Leucas cephalotes (Roth) Spreng. & 0.0235 & - & - & - \\
\hline Mentha arvensis $\mathrm{L}$. & 0.0235 & - & - & - \\
\hline Achillea millefolium $\mathrm{L}$. & 0.0196 & - & - & - \\
\hline Persicaria alpina (All.) H. Gross & 0.0196 & - & - & - \\
\hline Fagopyrum esculentum Moench & 0.0196 & - & - & - \\
\hline Solanum nigrum L. & 0.0196 & - & - & - \\
\hline Ziziphus nummularia (Burm.f.) Wight and Arn & 0.0196 & - & - & - \\
\hline Morus alba $\mathrm{L}$. & 0.0196 & - & - & - \\
\hline
\end{tabular}

${ }^{\dagger}$ Female taken as reference

Age- and gender-related knowledge of plants used for HDs Several informants' socio-cultural and demographic characteristics, in particular gender and age, are correlated with plant knowledge [32,33]. Such a relationship formally known as the age, gender, and dynamics of knowledge hypothesis [28] is specific to the type of knowledge studied but is also context-specific [28]. Whereas some authors found that men are more knowledgeable than women $[45,65]$, others found the contrary, especially where women served as the primary healthcare providers in their families [34, 66]. Similarly, older people tend to have greater knowledge of the local medicinal flora $[34,67]$ because the accumulation of medicinal plant knowledge is a life-long process [32]. Here, we found no evidence for either quantitative or qualitative differences between men and women or between the two generations considered ( $<40$ years, $\geq 40$ years). The lack of difference between men and women was also reported in the Sahelian zone of Africa [68] and may reflect the fact that both men and women are equally involved in health-related issues not only at a household level but also at a community level. However, the lack of difference among generations may be because HDs are common practices in the region and are

Table 4 Disease categories treated by herbal drinks

\begin{tabular}{lll}
\hline Diseases & Local names of diseases & Relative frequency of citations (\%) \\
\hline Gastrointestinal (GIT) diseases & Aantoonkebemaryaan & 17.43 \\
Respiratory diseases & Tanafsibemaryaaan & 12.60 \\
Fevers & Bukhaar & 9.92 \\
Nail, skin, and hair disorders & Jildi bemaryaan & 8.58 \\
Ear, nose, eye diseases & Kann, naak,aankhkebemaryaan & 8.04 \\
Glandular disorders & Ghadoodibemaryaan & 7.51 \\
Nervous disorders & Aasabibemaryaan & 6.97 \\
Sexual diseases & Jinsibemaryaan & 6.97 \\
Cardiovascular diseases & Qalbibemaryaan & 6.43 \\
Muscle and skeletal disorders & Pathoonkebemaryaan & 6.17 \\
Urinary disorders & Faazlatibemaryaan & 3.49 \\
Oral diseases & Moonhkebemaryaan & 3.22 \\
Infectious diseases & Wabaiamraaz & 2.68 \\
\hline
\end{tabular}




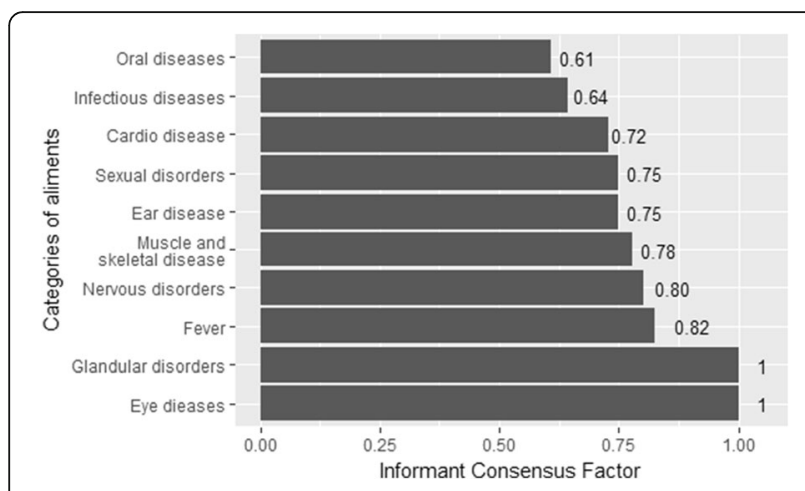

Fig. 5 Informant consensus factor for diseases treated by herbal drinks in Azad Jammu and Kashmir

accessible to everyone including youngers or because our sample did not include enough younger informants to capture such a trend. (All informants were aged at least 22 years, and only 17 informants were between 22 and 29 years).

\section{Treated disorders, plant part used, and forms of uses}

The people of Azad Jammu and Kashmir used HDs against 13 diseases. The finding that GIT diseases, respiratory diseases, and fevers were the most cited may suggest that these disorders are the most frequent in the study area. Different plant parts are used in treating various ailments depending on the type and condition of ailment treated. These plant parts are reported to accumulate a variety of phytochemicals that are important for treatment of various disorders by local communities of people [69, 70]. Leaves were found to be the most used plant part likely because leaves are easy to collect as compared to other plant parts [71] but also because leaves possess chemical constituents in larger quantities, which may be responsible for medicinal properties [72]. This information is in accordance with studies conducted in different regions of Pakistan $[73,74]$. After leaves, roots, which are also known to possess high concentrations of chemicals $[75,76]$, were the second most used plant part in this study. The main form of preparation reported by informants was decoction. Decoctions are easier to prepare because plant parts are only to be boiled with water [73]. Mostly, fresh plant parts are preferably used in preparation of HDs. Informants reported that drying the plant parts may cause their efficacy to decrease because the ingredients present are damaged to some extent. Both modes of preparation and prescriptions are commonly used in traditional herbal medicine, and similar results have been presented in previous ethnobotanical records that were carried out in the study area [77-80].

The medicinal HDs reported in this study for treatment of different diseases can also be exploited further for their pharmacological and phytochemical properties. Previous ethno-botanical studies conducted in various parts of the study area also reported recurrent practice of using medicinal plants against GIT ailments [38, 81]. Other conspicuous disorders cured by medicinal HDs include cardiovascular diseases, ear, nose, and eye diseases, glandular disorders, infectious diseases, muscle and skeletal disorders, nervous disorders, oral diseases, sexual diseases, and urinary disorders. The lowest cited ailments in this study were urinary disorders suggesting a weak prevalence of urinary problems in the study area. One of supporting reasons may be that people living in villages mostly use spring water or water from wells, which is clean from many impurities, so they have less chance of developing kidney or urinary problems. A number of disorders have been reported from the study area that are treated using medicinal HDs, and this could be attributed to lack of health facilities in remote and high-altitude areas.

In the present study, medicinal plants used as HDs were reviewed for the presence of different phytochemicals reported in previous literature (see Table 2, column "Active constituents"). Almost all the plants had been reported earlier for their one or more phytochemical compounds indicating their significance in medicinal treatments. The highest number of phytochemicals was reported for Bauhinia variegata, Bergenia ciliata, Isodon rugosus, Mentha arvensis, Oenothera rosea, Punica granatum, and Vitis vinifera. This information would be helpful in authenticating the use of these species as herbal drugs in curing various ailments and could be explored for their detailed phytochemical, biological, and pharmacological aspects to facilitate the scientific community in new drug discovery [82]. Flavonoids and alkaloids were reported in most of the HD species, indicating their significance. Flavonoids have been reported for their significant effects against many ailments and disorders such as inflammation, allergy, and thrombic disorders [83]. The presence of alkaloids could be related to the indication of cytotoxic, antibacterial, and analgesic properties in plants [84]. Pharmaceutical ethnobotanical studies are still very useful for identifying novel or scarcely reported medicinal uses of plants, which could provide the foundation for new drugs synthesis [85].

The values of ICF per disorder suggested that relatively few species were used for each ailment category, with only one species, namely, Quercus oblonga, used for glandular disorders (disorders cited by $7.51 \%$ of informants) and only one other, namely, Tagetes minuta, for eye diseases (disorders cited by $8.58 \%$ of informants). Infectious diseases $(\mathrm{ICF}=0.64)$ and oral diseases $(\mathrm{ICF}=$ 0.61) had the lowest ICF indicating a more diverse use of plant species compared to other disease categories. Based on the utilitarian redundancy model, species sharing the same therapeutic function are redundant and are predicted to experience a reduced use-impact because the 
use pressure is diffused across a greater number of species [86]. Thus, all things being equal, the loss or rarefaction of one species in ailment categories with lower ICF is predicted to have little overall effect on the ethnomedicinal practices in the region [87]. On the contrary, particular conservation attention should be paid to the single species used for eye diseases and glandular disorders.

\section{Most used species: medicinal uses and gender and generation effects}

The top five most used species for HDs were $V$. jatamansi, I. rugosus, O. acanthium, A. nilotica, and $V$. canescens. Their high UV may be due to their easy accessibility, availability, wide distribution in the area, and the strong ethnic culture to use these plants for medicinal purposes [88]. The medicinal and socio-economic importance of these species has been highlighted by many previous studies including ethno-pharmacology prospections in the Himalayan region. $V$. jatamansi is a well-known medicinal species in Asia $[89,90]$. The species is used in several Ayurvedic preparations and is known to cure obesity, skin diseases, insanity, epilepsy, and snake poisoning [91]. The essential oil and extract of the species is used in the flavoring, pharmaceutical, and fragrance industries, and about 30 products are commercially available [91]. I. rugosus is extensively used as TM for the management of various types of pain including tooth ache, gastric pain, abdominal pain, ear ache, and generalized body pain [92, 93]. O. acanthium has application in medical practice as a bactericide, cardiotonic, and hemostatic agent, is used against hypotonicity [94, 95], and is a great bio-oil source [96]. O. acanthium is sometimes sold as an ornamental plant and has reportedly been used to treat cancers and ulcers and to diminish discharges of mucous membranes [96].

A. nilotica is a widespread multipurpose tree used extensively for the treatment of various diseases, e.g., colds, bronchitis, diarrhea, dysentery, biliousness, bleeding piles, and leukoderma [97], and its bioactivity has been proven by many studies $[94,98]$. $V$. canescens is commonly used as TM in the north-west Himalaya for the treatment of protozoan infections and fever including malaria [21], and its anti-malarial activity was proven by Verma, Dua [99].

A significant relationship of the UV with gender was found for only 1 species out of the top 14 most used species, namely, for $V$. jatamansi. This finding corroborates the hypothesis that the effect of gender and age category on the medicinal uses of plant species is species-specific and context-specific [28].

\section{Novelty and added value for the study region}

The comparison of species reported in the present study with those in previous literature of the same region revealed 17, i.e., 22\%, new species used as HD species including Adiantum venustum D. Don, Euphorbia illirica Lam., Fagonia cretica L., Fagopyrum esculentum Moench, Gerbera gossypina Royle, Geum adnatum Wall., Isodon rugosus (Wall. ex Benth.) Codd, Laphangium affine (D.Don) Tzvelev, Leucas cephalotes (Roth) Spreng, Muehlenbeckia hastulata (Sm.) I.M. Johnst., Onopordum acanthium L., Pimpinella diversifolia DC., Smilax aspera L., Solanum surattense Burm. f., Solanum virginianum L., and Vitis vinifera L. This could be linked to the fact that $T M$ is a dynamic system and is based on a recurrent trial and error process that is transmitted across generations and guides further use of plants [100, 101].

Implications for public health and environmental policies From the results provided, GIT disorders (stomach related health problems) and respiratory disorders (cough, bronchitis) were the most prevalent health problems in the study area. Stomach disorders probably spread in these areas due to malnutrition and unhygienic use of food stuffs. Respiratory problems can be attributed to the high altitude of the study area, where the air is cold. People traditionally use food medicines to treat such diseases, which in many cases are quite effective. Therefore, the present findings suggest that public-health administrators should devise some health policies regarding the general health problems in the study area and the TM practiced by the indigenous community of the area as part of their primary healthcare.

\section{Conclusion}

Recently, the utilization of medicinal plants has gained much attention due to their fewer side effects as herbal remedies. The study area has a diversity of medicinal plants, which are still used against many ailments, but there is lack of traditional knowledge transfer among the new generation. From ancient times, the use of hot watery infusions made from wild or cultivated plants have been employed as a remedy for a number of ailments. In present study, 72 medicinal plants used as HDs (decoction, infusion, tea, juices) for curing various ailments were documented. The most preferred form of utilization was decoction, and herbs were the dominant life form exploited. Leaves were used mostly in preparation of medicinal HDs. The key informants were mostly male between 40 and 50 years old, and some herbalists also provided the required information. The wealth of original knowledge obtained from the present work strengthens the significance of expanding the study to other parts of the study area. The therapeutic uses of the HDs provided basic data for further research focused on phytochemical and pharmacological studies and conservation of the most important species. 


\section{Abbreviations}

ANOSIM: Analysis of similarities; GLM: General linear model; HD: Herbal drink; ICF: Informant consensus factor; RFC: Relative frequency of citation; TM: Traditional medicine; UV: Use value

\section{Acknowledgements}

The authors warmly thank local communities of the study area for giving appropriate and valuable information about utilization of herbal drinks as a remedy for various ailments.

\section{Funding}

There was no funding.

\section{Availability of data and materials}

The datasets used and/or analyzed during the current study are available from the corresponding author on reasonable request.

\section{Consent to participate}

Not applicable.

\section{Authors' contributions}

$\mathrm{KM}, \mathrm{MA}$, and $\mathrm{MZ}$ conceived the work with contributions from RCG and VKS. NR carried out the field surveys and data collection.NR, MZ, KM, and VKS processed the data and performed the statistical analyses. NR, RCG, MZ, and KM drafted the manuscript. RCG, MA, and VKS revised the manuscript critically to its present form. All authors read the final manuscript and agreed to its submission.

\section{Ethics approval}

For collection of plant material, field studies were conducted in accordance with Pakistan legislation. Vouchers of plant collected were deposited in the National Herbarium, Islamabad, Pakistan. Authors comply with the IUCN Policy Statement on Research Involving Species at Risk of Extinction and the Convention on the Trade in Endangered Species of Wild Fauna and Flora.

\section{Consent for publication}

Not applicable.

\section{Competing interests}

The authors declare that they have no competing interests.

\section{Publisher's Note}

Springer Nature remains neutral with regard to jurisdictional claims in published maps and institutional affiliations.

\section{Author details}

${ }^{1}$ Department of Botany, Mirpur University of Science and Technology, Mirpur, Azad Kashmir, Pakistan. 'Laboratoire de Biomathématiques et d'Estimations Forestières, Faculty of Agronomic Sciences, University of Abomey-Calavi, 04BP 1525 Cotonou, Benin. ${ }^{3}$ Department of Plant Sciences, Quaid- I-Azam University, Islamabad, Pakistan.

Received: 9 May 2017 Accepted: 12 February 2018

Published online: 21 February 2018

\section{References}

1. Grundy, C., et al., WHO global atlas of traditional, complementary and alternative medicine. 2005.

2. Gogoi B, Dutta M, Mondal P. Various ethno medicinal plants used in the preparation of Apong, a traditional beverage use by mising tribe of upper Assam. J Appl Pharm Sci. 2013;3(4):S85.

3. WHO, WHO traditional medicine strategy 2002-2005. 2002.

4. Chen $\mathrm{S}$, et al. A renaissance in herbal medicine identification: from morphology to DNA. Biotechnol Adv. 2014;32(7):1237-44

5. Chevallier, A., Encyclopedia of herbal medicine. 2016: Penguin.

6. Sewell RD, Rafieian-Kopaei M. The history and ups and downs of herbal medicine usage. J HerbMed Pharmacol. 2014;3(1):1-3.

7. Alves, R.R.N., G.G. Santana, and I.L. Rosa, The role of animal-derived remedies as complementary medicine in Brazil, in Animals in traditional folk medicine. 2013, Springer. p. 289-301.
8. Chellappandian M, et al. Documentation and quantitative analysis of local ethnozoological knowledge among traditional healers of Theni district, Tamil Nadu, India. J Ethnopharmacol. 2014;154(1):116-30.

9. Martínez GJ. Use of fauna in the traditional medicine of native Toba (qom) from the Argentine Gran Chaco region: an ethnozoological and conservationist approach. Ethnobiol Conservation. 2013;2

10. Williams VL, Whiting MJ. A picture of health? Animal use and the faraday traditional medicine market, South Africa. J Ethnopharmacol. 2016;179:265-73.

11. Wijenayake $\mathrm{A}$, et al. The role of herbometallic preparations in traditional medicine-a review on mica drug processing and pharmaceutical applications. J Ethnopharmacol. 2014;155(2):1001-10.

12. Wu M-L, et al. Lead, mercury, and arsenic poisoning due to topical use of traditional Chinese medicines. Am J Med. 2013;126(5):451-4.

13. Shipley GP, Kindscher K. Evidence for the Paleoethnobotany of the Neanderthal: a review of the literature. Scientifica. 2016;2016

14. Solecki RS. Shanidar IV, a Neanderthal flower burial in northern Iraq. Science. 1975;190:880-1.

15. Samant SS, Dhar U, Palni LMS. Medicinal Plants of Indian Himalaya. 1998 Gyanodaya Prakashan. Almora: Pant Inst. of Himalayan Environment and Development; 1998. p 163

16. Shinwari ZK. Medicinal plants research in Pakistan. J Med Plants Res. 2010; 4(3):161-76.

17. Baquar, S.R., Medicinal and poisonous plants of Pakistan. Medicinal and poisonous plants of Pakistan., 1989.

18. Qureshi RA, et al. Indigenous medicinal plants used by local women in southern Himalayan regions of Pakistan. Pak J Bot. 2009;41(1):19-25.

19. Shinwari MI, Khan MA. Folk use of medicinal herbs of Margalla hills national park, Islamabad. J Ethnopharmacol. 2000;69(1):45-56.

20. Shinwari ZK, Gilani SS. Sustainable harvest of medicinal plants at Bulashbar Nullah, Astore (northern Pakistan). J Ethnopharmacol. 2003;84(2):289-98.

21. Haq F, Ahmad H, Alam M. Traditional uses of medicinal plants of Nandiar Khuwarr catchment (district Battagram), Pakistan. J Med Plants Res. 2011:5(1):39-48.

22. Hamayun M, Khan MA, Begum S. Marketing of medicinal plants of UtrorGabral valleys, swat, Pakistan Ethnobotanical Leaflets. 2003:2003(1):13.

23. Hamayun $M$, et al. Folk medicinal knowledge and conservation status of some economically valued medicinal plants of district swat, Pakistan Lyonia. 2006:11(2):101-113.

24. Shaheen S, et al. Ethnopharmacological And Systematic Studies Of Selected Medicinal Plants Of Pakistan. Pak J Sci. 2014;66(2):175-180.

25. Shinde VM, et al. Application of quality control principles to herbal drugs. Int J Phytoremediation. 2009;1(1):4-11.

26. Sõukand $\mathrm{R}$, et al. Plants used for making recreational tea in Europe: a review based on specific research sites. J Ethnobiol Ethnomed. 2013;9(1):58.

27. Ahmad $M$, et al. Ethnopharmacological survey on medicinal plants used in herbal drinks among the traditional communities of Pakistan. J Ethnopharmacol. 2016;184:154-86.

28. Gaoue OG, et al. Theories and major hypotheses in ethnobotany. Econ Bot. 2017:1-19.

29. Moerman DE. Meaning, Medicine, and the "placebo effect". Vol. 28. 2002: Cambridge University Press Cambridge.

30. Qureshi R, Bhatti GR, Memon RA. Ethnomedicinal uses of herbs from northern part of Nara desert, Pakistan. Pak J Bot. 2010;42(2):839-51.

31. de Albuquerque UP, et al. The use of plants in the medical system of the Fulni-ô people (NE Brazil): a perspective on age and gender. J Ethnopharmacol. 2011;133(2):866-73.

32. Hanazaki $\mathrm{N}$, et al. Evidence of the shifting baseline syndrome in ethnobotanical research. J Ethnobiol Ethnomed. 2013:9(1):75

33. McCarter J, Gavin MC. Assessing variation and diversity of ethnomedical knowledge: a case study from Malekula Island, Vanuatu. Economic Botany. 2015:69(3):251-61

34. Torres-Avilez, W., P.M.d. Medeiros, and U.P. Albuquerque, Effect of gender on the knowledge of medicinal plants: systematic review and meta-analysis. Evid Based Complement Alternat Med, 2016. 2016

35. Abbasi MK, Zafar M, Khan SR. Influence of different land-cover types on the changes of selected soil properties in the mountain region of Rawalakot Azad Jammu and Kashmir. Nutr Cycl Agroecosyst. 2007;78(1):97-110

36. Ishtiaq $\mathrm{M}$ et al. Medicinal plant diversity in the flora of Leepa Valley, Muzaffarabad (AJK), Pakistan. Afr J Biotechnol. 2014;11(13):3087-98. 
37. Amjad MS, Arshad M. Ethnobotanical inventory and medicinal uses of some important woody plant species of Kotli, Azad Kashmir, Pakistan. Asian Pacific J Trop Biomed. 2014;4(12):952-8.

38. Khan $\mathrm{M}$, et al. Ethnobotanical study about medicinal plants of Poonch valley Azad Kashmir. J Animal Plant Sci. 2012;22:493-500.

39. Dagnelie, P., Statistique théorique et appliquée. Vol. 2. 1998: De Boeck Université.

40. Goodman, L.A., Snowball sampling. Annals Mathematical Stat, 1961: p. 148-170.

41. Jain, S.K. and R.R. Rao, A handbook of field and herbarium methods. New Delhi: Today and Tomorrow's Printers and Publishers xvi, 157p.-Illus.. General (KR, 197700062), 1977.

42. Ethnobiology, I.S.O., International Society of Ethnobiology Code of Ethics (with 2008 additions). 2006.

43. Oksanen, J., et al., ... Wagner, H.(2016). vegan: Community Ecology Package Software.

44. Salako V, Adebanji A, Kakaï RG. On the empirical performance of non-metric multidimensional scaling in vegetation studies. Int J Appl Math Stat. 2013; 36:54-67.

45. Etongo $D$, et al. Assessing use-values and relative importance of trees for livelihood values and their potentials for environmental protection in Southern Burkina Faso. Environ Dev Sustain. 2017;19(4):1141-66.

46. Phillips O, Gentry AH. The useful plants of Tambopata, Peru: I. Statistical hypotheses tests with a new quantitative technique. Econ Bot. 1993:47(1): $15-32$.

47. Team, R.C., R: A Language and Environment for Statistical Computing. Vienna, Austria: R Foundation for Statistical Computing; 2014. R Foundation for Statistical Computing 2016.

48. Khan SW, Khatoon S. Ethno botanical studies on useful trees and shrubs of Haramosh and Bugrote valleys in Gilgit Nothern areas of Pakistan. Pak J Bot. 2007;39(3):699-710.

49. Abid R, Ather A. Receptacle micro-characters and their taxonomic significance for the Tribe Gnaphalieae (Asteraceae) From Pakistan And Kashmir. Int J Biol Biotech. 2016;13(2):183-191.

50. Dar GH, Nordenstam B. Asteraceae in the Flora of Sind Valley, Kashmir Himalaya, India. Nelumbo. 2014;56:14-88.

51. Moerman DE. Symbols and selectivity: a statistical analysis of native American medical ethnobotany. J Ethnopharmacol. 1979;1(2):111-9.

52. Moerman DE. An analysis of the food plants and drug plants of native North America. J Ethnopharmacol. 1996;52(1):1-22.

53. Mesfin F, Demissew S, Teklehaymanot T. An ethnobotanical study of plants used by people in Zegie Peninsula, Northwestern Ethiopia. J Ethnobiol Ethnomed. 2009;5:28.

54. Bhattarai $\mathrm{S}$, et al. The use of medicinal plants in the trans-Himalayan arid zone of mustang district, Nepal. J Ethnobiol Ethnomed. 2010;6(1):1.

55. Heinrich $M$, et al. Medicinal plants in Mexico: healers' consensus and cultural importance. Soc Sci Med. 1998;47(11):1859-71.

56. Addo-Fordjour $P$, et al. Liana species richness, abundance and relationship with trees in the Bobiri forest reserve, Ghana: impact of management systems. For Ecol Manag. 2009;257(8):1822-8.

57. ljaz F, et al. Ethno medicinal study upon folk recipes against various human diseases in Sarban Hills, Abbottabad, Pakistan. World J Zool. 2015;10(1):41-6.

58. Uprety $Y$, et al. Indigenous use and bio-efficacy of medicinal plants in the Rasuwa District, Central Nepal. J Ethnobiol Ethnomed. 2010;6(1):1.

59. Giday $M$, et al. Medicinal plants of the Shinasha, Agew-awi and Amhara peoples in northwest Ethiopia. J Ethnopharmacol. 2007;110(3):516-25.

60. Gazzaneo LRS, De Lucena RFP, de Albuquerque PU. Knowledge and use of medicinal plants by local specialists in an region of Atlantic Forest in the state of Pernambuco (northeastern Brazil). J Ethnobiol Ethnomed. 2005;1(1):1.

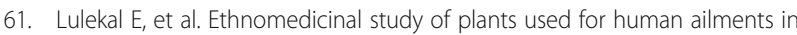
Ankober District, north Shewa zone, Amhara region, Ethiopia. J Ethnobiol Ethnomed. 2013:9(1):1.

62. Giday $M$, et al. Medicinal plant knowledge of the bench ethnic group of Ethiopia: an ethnobotanical investigation. J Ethnobiol Ethnomed. 2009;5(1):1.

63. de Albuquerque UP. Re-examining hypotheses concerning the use and knowledge of medicinal plants: a study in the Caatinga vegetation of NE Brazil. J Ethnobiol Ethnomed. 2006;2(1):30.

64. Voeks RA. Disturbance pharmacopoeias: medicine and myth from the humid tropics. Ann Assoc Am Geogr. 2004;94(4):868-88.

65. Souto T, Ticktin T. Understanding interrelationships among predictors (age, gender, and origin) of local ecological Knowledge1. Econ Bot. 2012;66(2):149-64
66. Begossi A, Hanazaki N, Tamashiro JY. Medicinal plants in the Atlantic Forest (Brazil): knowledge, use, and conservation. Hum Ecol. 2002;30(3):281-99.

67. Ayantunde AA, et al. Botanical knowledge and its differentiation by age, gender and ethnicity in southwestern Niger. Hum Ecol. 2008;36(6):881-9.

68. Lykke A, Kristensen M, Ganaba S. Valuation of local use and dynamics of 56 woody species in the Sahel. Biodivers Conserv. 2004;13(10):1961-90.

69. Shah GM, Jamal Z, Hussain M. Phytotherapy among the rural women of district Abbotabad. Pak J Bot. 2013;45:253-61.

70. Shah NA, Khan MR, Nadhman A. Antileishmanial, toxicity, and phytochemical evaluation of medicinal plants collected from Pakistan. Biomed Res Int. 2014;2014

71. Tuttolomondo T, et al. Ethnobotanical investigation on wild medicinal plants in the Monti Sicani Regional Park (Sicily, Italy). J Ethnopharmacol. 2014;153(3):568-86.

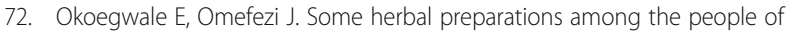
Isoko clan of Delta state, Nigeria. J Appl Sci. 2001;4:2350-71.

73. Ahmad $\mathrm{M}$, et al. An ethnobotanical study of medicinal plants in high mountainous region of Chail valley (District Swat-Pakistan). J Ethnobiol Ethnomed. 2014;10(1):1.

74. Bano A, et al. Quantitative ethnomedicinal study of plants used in the skardu valley at high altitude of Karakoram-Himalayan range, Pakistan. J Ethnobiol Ethnomed. 2014;10(1):1.

75. Srithi $\mathrm{K}$, et al. Medicinal plant knowledge and its erosion among the Mien (Yao) in northern Thailand. J Ethnopharmacol. 2009;123(2):335-42.

76. Moore PD. Trials in bad taste. Nature. 1994;372(6505):410-1.

77. Mahmood A, et al. Ethnobotanical survey of plants from Neelum, Azad Jammu and Kashmir, Pakistan. Pak J Bot. 2011;43:105-10.

78. Ishtiaq M, Maqbool M, Hussain T. Interrelationship of cultural diversity and biodiversity and its impact on conservation. Pak J Botany. 2012;44:245-56.

79. Ahmad KS, et al. Floristic diversity and ethnobotany of Senhsa, District Kotli, Azad Jammu and Kashmir (Pakistan). Pak J Bot. 2012;44:195-201.

80. Ahmad KS, Habib S. Indigenous knowledge of some medicinal plants of Himalaya region, Dawarian Village, Neelum Valley, Azad Jammu and Kashmir, Pakistan. Universal J Plant Sci. 2014;2(2):40-7.

81. Amjad MS, Arshad M, Qureshi R. Ethnobotanical inventory and folk uses of indigenous plants from Pir Nasoora National Park, Azad Jammu and Kashmir. Asian Pacific J Tropical Biomed. 2015;5(3):234-41.

82. Bellik $Y$, et al. Molecular mechanism underlying anti-inflammatory and antiallergic activities of phytochemicals: an update. Molecules. 2012;18(1):322-53.

83. Edeoga $\mathrm{H}$, Eriata D. Alkaloid, tannin and saponin contents of some Nigeria medicinal plants. J Med Aromatic Plant Sci. 2001;23:344-9.

84. Okwu D. Phytochemicals and vitamin content of indigenous spices of south eastern Nigeria. J Sustain Agric Environ. 2004;6(1):30-7.

85. Bonet M, Valles J. Pharmaceutical ethnobotany in the Montseny biosphere reserve (Catalonia, Iberian Peninsula). General results and new or rarely reported medicinal plants. J Pharm Pharmacol. 2003;55(2):259-70.

86. de Albuquerque UP, de Oliveira RF. Is the use-impact on native caatinga species in Brazil reduced by the high species richness of medicinal plants? J Ethnopharmacol. 2007:113(1):156-70.

87. Nascimento, A.L.B., et al., Utilitarian redundancy: conceptualization and potential applications in ethnobiological research, in Evolutionary ethnobiology. Switzerland: Springer International Publishing; 2015. p. 121-130.

88. Ullah S, et al. Ethnomedicinal plant use value in the Lakki Marwat District of Pakistan. J Ethnopharmacol. 2014;158:412-22.

89. Bhatt ID, et al. Characterization of essential oil composition, phenolic content, and antioxidant properties in wild and planted individuals of Valeriana jatamansi Jones. Sci Hortic. 2012;136:61-8.

90. Dua V, et al. Insecticidal activity of Valeriana jatamansi (Valerianaceae) against mosquitoes. J Am Mosq Control Assoc. 2008;24(2):315-8.

91. Prakash V. Indian Valerianaceae: a monograph on medicinally important family. India: Scientific Publishers; 1999.

92. Zeb A, et al. Anti-nociceptive activity of ethnomedicinally important analgesic plant Isodon rugosus wall. ex Benth: mechanistic study and identifications of bioactive compounds. Front Pharmacol 2016;7:1-10

93. Zeb A, et al. Phytochemical and toxicological investigations of crude methanolic extracts, subsequent fractions and crude saponins of Isodon rugosus. Biol Res. 2014;47(1):57.

94. Kalaivani T, Mathew L. Free radical scavenging activity from leaves of Acacia nilotica (L.) wild. ex Delile, an Indian medicinal tree. Food Chem Toxicol. 2010;48(1):298-305. 
95. Sharifi N, et al. Discovery of new angiotensin converting enzyme (ACE) inhibitors from medicinal plants to treat hypertension using an in vitro assay. DARU J Pharm Sci. 2013;21(1):74.

96. Gerçel HF. Bio-oil production from Onopordum acanthium L. by slow pyrolysis. J Anal Appl Pyrolysis. 2011;92(1):233-8.

97. Ambasta S. The useful plants of India. New Delhi: CSIR; 1986.

98. Sultana B, Anwar F, Przybylski R. Antioxidant activity of phenolic components present in barks of Azadirachta indica, Terminalia arjuna, Acacia nilotica, and Eugenia jambolana Lam. Trees. Food Chem. 2007;104(3):1106-14.

99. Verma $\mathrm{G}$, et al. Anti-malarial activity of Holarrhena antidysenterica and Viola canescens, plants traditionally used against malaria in the Garhwal region of north-west Himalaya. Malar J. 2011;10(1):20.

100. Agyepong IA. Malaria: ethnomedical perceptions and practice in an Adangbe farming community and implications for control. Soc Sci Med. 1992;35(2):131-7.

101. Berkes F, Colding J, Folke C. Rediscovery of traditional ecological knowledge as adaptive management. Ecol Appl. 2000;10(5):1251-62.

102. Deshpande S, Kadam D. Phytochemical analysis and antibacterial activity of Acacia nilotica against Streptococcus mutans. Phytochem Anal. 2013;15:0.69.

103. Souza T, et al. Phytochemical screening of Achillea Millefolium harvested at Araraquara-SP. Rev Bras Plant Med Botucatu. 2006:8:151-4.

104. Pan Y, et al. In vitro modulatory effects of Andrographis paniculata, Centella asiatica and Orthosiphon stamineus on cytochrome P450 2C19 (CYP2C19). J Ethnopharmacol. 2011;133(2):881-7.

105. Khan SU, et al. Heavy metals content, phytochemical composition, antimicrobial and insecticidal evaluation of Elaeagnus angustifolia. Toxicol Ind Health. 2016;32(1):154-61.

106. Azimova S. Occurrence of Phytoecdysteroids in plant species. Phytochemistry. 1971;10:2225.

107. Ahmed A, et al. Efficacy of Adiantum capillus veneris Linn in chemically induced urolithiasis in rats. J Ethnopharmacol. 2013;146(1):411-6.

108. Ganie SA, et al. In vitro antioxidant and cytotoxic activities of Arnebia benthamii (Wall ex. G. Don): a critically endangered medicinal plant of Kashmir valley. Oxidative Med Cell Longev. 2014:2014.

109. Dhale, D., Phytochemical screening and antimicrobial activity of Bauhinia variegata Linn. J Ecobiotechnol. 2011;3(9):4-7.

110. Bhardwaj D, Kaushik N. Phytochemical and pharmacological studies in genus Berberis. Phytochem Rev. 2012;11(4):523-42.

111. Gupta AK, Dey BK. Phytochemical screening and biological evaluation of different parts of plant Bergenia Ciliata. J Pharmacognosy and Phytochem. 2014;3(4):220-4

112. ElSohly MA, Slade D. Chemical constituents of marijuana: the complex mixture of natural cannabinoids. Life Sci. 2005;78(5):539-48.

113. Sahreen S, et al. Effect of Carissa opaca leaves extract on lipid peroxidation, antioxidant activity and reproductive hormones in male rats. Lipids Health Dis. 2013;12(1):1

114. Inoue $\mathrm{K}$, et al. A secoiridoid glucoside of Jasminum humile var. revolutum. Phytochemistry. 1982;21(2):359-61.

115. Mehmood N, et al. Antioxidant, antimicrobial and phytochemical analysis of Cichorium Intybus seeds extract and various organic fractions. Iranian J Pharm Res. 2012;11(4):1145-51.

116. Rauf A, et al. Phosphodiesterase-1 inhibitory activity of two flavonoids isolated from Pistacia Integerrima JL Stewart Galls. Evid Based Complement Alternat Med. 2015;2015

117. Asaolu M, Oyeyemi O, Olanlokun J. Chemical compositions, phytochemical constituents and in vitro biological activity of various extracts of Cymbopogon citratus. Pak J Nutr. 2009:8(12):1920-2.

118. Sharma RK, et al. Antioxidant activities and phenolic contents of the aqueous extracts of some Indian medicinal plants. J Med Plants Res. 2009; 3(11):944-8

119. Ahmad MS, et al. Phytochemical analysis and biological activities of Diospyros lotus L. fruit extracts. Int J Pharm Chem. 2014;4(4):155-9.

120. Cui JF, et al. Analysis of alkaloids in chinese ephedra species by gas chromatographic methods. Phytochem Anal. 1991;2(3):116-9.

121. Saleem U, et al. Physicochemical and phytochemical analysis of Euphorbia helioscopia (L.). Pak J Pharm Sci. 2014;27(3):577-585.

122. Sharma SK, Singh J, Singh S. Pharmacognostical and phytochemical investigation of euphorbia prostrata ait. Int J Pharm Sci Res. 2012;3(4):1043.

123. Khalik SA, et al. Triterpenoid saponins from Fagonia cretica. Phytochemistry. 2000;54(8):853-9.
124. Iwashina T. Flavonoid properties of five families newly incorporated into the order Caryophyllales. Bull Natl Mus Nat Sci. 2013;39:25-51.

125. Bousetla A, et al. Phytochemical study of Algerian Foeniculum vulgare mill (Apiaceae). Pharm Lett. 2013;5(6):9-11.

126. Najda, A, et al. Comparative analysis of secondary metabolites contents in Fragaria vesca L. fruits. Ann Agric Environ Med. 2014;21(2):339-343.

127. Wani BA, Ramamoorthy D, Ganai BA. Preliminary phytochemical screening and evaluation of analgesic activity of methanolic extract of roots of Gentiana kurroo Royle in experimental animal models. Int J Pharm Pharm Sci. 2011;3(4):164-6.

128. Ismail M, et al. Chemical constituents and antioxidant activity of geranium wallichianum. Rec Nat Prod. 2009;3(4):193-7.

129. Mir MA, Angmo S, Ahmad B. Comparative phytochemical screening for the qualitative and quantitative analysis of phytochemicals of Gerbera Viridifolia, Gerbera Jamesonii. Indo Am J Pharmaceutical Res. 2014:4(8):3462-7.

130. Shahani S, et al. Anti-helicobacter pylori activity of the methanolic extract of Geum Iranicum and its main compounds. Zeitschrift für Naturforschung C. 2012;67(3-4):172-80

131. Kamal Z, et al. Anticholinesterse and antioxidant investigations of crude extracts, subsequent fractions, saponins and flavonoids of atriplex laciniata L.: potential effectiveness in Alzheimer's and other neurological disorders. Biol Res. 2015;48(1):1.

132. Jha DK, et al. Detection and confirmation of alkaloids in leaves of Justicia adhatoda and bioinformatics approach to elicit its anti-tuberculosis activity. Appl Biochem Biotechnol. 2012;168(5):980-90.

133. Xi Z, et al. Anti-complementary activity of flavonoids from Gnaphalium affine D. Don. Food Chemistry. 2012;130(1):165-70.

134. Sailor Girish U, et al. Research Paper Pharmacognostical and Preliminary Phytochemical Investigation of Leucas cephalotes (Roth) Spreng. Int J Pharmaceutical Res. 2010:2(1).

135. Mojab F, et al. Phytochemical screening of some species of Iranian plants. Iranian J Pharmaceutical Res. 2010:77-82.

136. Malik F, et al. Phyto-chemical analysis, anti-allergic and anti-inflammatory activity of Mentha Arvensis in animals. Afr J Pharm Pharmacol. 2012;6:613-9.

137. Riahi $L$, et al. Phytochemistry, antioxidant and antimicrobial activities of the essential oils of Mentha rotundifolia L. in Tunisia. Ind Crop Prod. 2013:49:883-9.

138. Naik R, et al. Bioactive benzofuran derivatives: moracins $A-Z$ in medicinal chemistry. Eur J Med Chem. 2015:90:379-93.

139. Liu C, et al. Artemisia Judaica L.: micropropagation and antioxidant activity. Jiotechnol. 2004;110(1):63-71.

140. Bhuvaneshwari L, et al. Phytochemical analysis \& antibacterial activity of Nerium Oleander. Anc Sci Life. 2007;26(4):24

141. Akinmoladun AC, et al. Phytochemical constituent and antioxidant activity of extract from the leaves of Ocimum gratissimum. Sci Res Essay. 2007;2(5): $163-6$.

142. Averett JE, Huang S, Wagner WL. Flavonoid analysis of Oenothera speciosa (Onagraceae). Southwest Nat, 1987: p. 117-120.

143. Chebbi Mahjoub, R., et al., Chloroformic and methanolic extracts of Olea europaea $L$. leaves present anti-inflammatory and analgesic activities. ISRN Pharmacol. 2011;2011:1-5.

144. Formisano C, et al. Phytochemical profile and apoptotic activity of. Planta Med. 2012;78:1651-60.

145. Joy P, et al. Medicinal plants. Tropical Horticulture. 1998;2:449-632.

146. Raghavendra M, Satish S, Raveesha K. Phytochemical analysis and antibacterial activity of Oxalis corniculata; a known medicinal plant. Myscience. 2006;1(1):72-8.

147. Uddin G, Sadat A, Siddiqui BS. Phytochemical screening, in vitro antioxidant and antimicrobial activities of the crude fractions of Paeonia emodi wall. Ex Royle. Middle-East J Sci Res. 2013:17(3):367-73.

148. Khan RA, et al. Phytochemical, antioxidant and cytotoxic activities of Periploca aphyla and Mentha Longifolia, selected medicinal plants of District Bannu, Pakistan. Afr J Pharm Pharmacol. 2012;6(45):3130-5.

149. Bottini AT, et al. Oxiranylphenyl esters from Pimpinella Diversifolia. Phytochemistry. 1985;25(1):207-11.

150. Egharevba $\mathrm{HO}$, et al. Phytochemical analysis and antimicrobial activity of Punica granatum L.(fruit bark and leaves). New York Sci J. 2010;3(3):91-8.

151. Okuda T, Ito H. Tannins of constant structure in medicinal and food plants-hydrolyzable tannins and polyphenols related to tannins. Molecules. $2011 \cdot 16(3) \cdot 2191-217$ 
152. Kumar MH, Spandana M. Qualitative and quantitative study of anthraquinone derivatives in the root extract of Rheum australe of Nepal (syn. Rheum emodi) by HPLC. J Pharmacogn Phytochem. 2013:2(4).

153. Lee J, Dossett M, Finn CE. Rubus fruit phenolic research: the good, the bad, and the confusing. Food Chem. 2012;130(4):785-96.

154. Ali MS, et al. In vitro antioxidant, cytotoxic, thrombolytic activities and phytochemical evaluation of methanol extract of the a. philippense L. leaves. Asian Pacific J Tropical Biomed. 2013;3(6):464-9.

155. Djaafar Z, Ridha OM. Phytochemical study of selected medicinal plant solanum Nigrum, the Algerian Desert. Int Letters Chem Physics and Astronomy. 2014;1:25.

156. Nawaz $\mathrm{H}$, et al. Isolation and spectral assignments of lipoxygenase inhibiting triterpene from solanum surrattense. Asian J Chem. 2014;26(4):1091.

157. Aiyegoro OA, Okoh Al. Preliminary phytochemical screening and in vitro antioxidant activities of the aqueous extract of Helichrysum longifolium DC. BMC Complement Altern Med. 2010;10(1):21.

158. Brahmachari G, et al. Swertia (Gentianaceae): chemical and pharmacological aspects. Chem Biodivers. 2004;1 (11):1627-51.

159. Vázquez AM, et al. Phytochemistry of Tagetes minuta L.(Asteraceae) from Córdoba, Argentina: comparative study between essential oil and HS-SPME analyses. Bol Latinoamer Caribe Plant Med Aromat. 2011;10:351-62.

160. Abukakar M, Ukwuani A, Shehu R. Phytochemical screening and antibacterial activity of Tamarindus indica pulp extract. Asian J Biochem. 2008:3(2):134-8.

161. Schütz K, Carle R, Schieber A. Taraxacum - a review on its phytochemical and pharmacological profile. J Ethnopharmacol. 2006;107(3):313-23.

162. Perianayagam JB, Sharma S, Pillai K. Anti-inflammatory activity of Trichodesma Indicum root extract in experimental animals. J Ethnopharmacol. 2006;104(3):410-4

163. Ponce MA, et al. Flavonoids from shoots and roots of Trifolium repens (white clover) grown in presence or absence of the arbuscular mycorrhizal fungus Glomus intraradices. Phytochemistry. 2004;65(13):1925-30.

164. Gränicher F, Christen P, Kapetanidis I. Essential oils from normal and hairy roots of Valeriana officinalis var. sambucifolia. Phytochemistry. 1995;40(5):1421-4.

165. Warashina T, Miyase T, Ueno A. Phenylethanoid and lignan glycosides from Verbascum thapsus. Phytochemistry. 1992;31(3):961-5.

166. Rehecho S, et al. Chemical composition, mineral content and antioxidant activity of Verbena officinalis L. LWT-Food Sci Technol. 2011;44(4):875-82.

167. Herrmann A, et al. The alpine violet, Viola biflora, is a rich source of cyclotides with potent cytotoxicity. Phytochemistry. 2008;69(4):939-52.

168. Kammerer D, et al. Polyphenol screening of pomace from red and white grape varieties (Vitis Vinifera L.) by HPLC-DAD-MS/MS. J Agric Food Chem. 2004;52(14):4360-7.

169. Singh TP, Singh OM. Phytochemical and pharmacological profile of Zanthoxylum Armatum DC.-an overview. Indian J Nat Prod Resour. 2011; 2(3):275-85.

170. Kaleem WA, et al. Pharmacological and phytochemical studies of genus Zizyphus. Middle-East J Sci Res. 2014;21(8):1243-63.

\section{Submit your next manuscript to BioMed Central and we will help you at every step:}

- We accept pre-submission inquiries

- Our selector tool helps you to find the most relevant journal

- We provide round the clock customer support

- Convenient online submission

- Thorough peer review

- Inclusion in PubMed and all major indexing services

- Maximum visibility for your research

Submit your manuscript at www.biomedcentral.com/submit

CBiomed Central 